\title{
METHOD OF INCREASING ACCURACY OF INFRARED TEMPERATURE MEASUREMENT
}

\section{МЕТОД ПЦДВИЩЕННЯ ТОЧНОСТІ ВИМІРЮВАННЯ ТЕМПЕРАТУРИ ЗА ІНФРАЧЕРВОНИМ ВИПРОМІНЕННЯМ}

\author{
Nataliya Hots, Vasyl Parakuda, \\ Lviv Polytechnic National University, Ukraine; \\ Yuliia Dzikovska, \\ Novovolynsk Electromechanical College,Ukraine; e-mail: pastsvitlo@gmail.com \\ Гоц Н., Паракуда В., \\ Начіональний університет "Львівська політехніка"; \\ Дзіковська Ю., \\ Нововолинський електромеханічний коледж
}

\begin{abstract}
Object temperature diagnostics by means of infrared temperature measurements as well as measurements of temperature gradients are considered. Values of the surface temperature carry information about the internal structure, defects and their location of measured object. This information becomes quite important for preventive measures and repairs of technical objects.

The world production of infrared thermometers and pyrometers, thermal imagers and infrared cameras is quite significant. These measuring devices are small-sized, with low power consumption at comparatively high performance and the possibility of real-time processing information. It contributes to expanding the radiation thermometers and infrared cameras application in industry. However, low accuracy of infrared temperature measurements can lead to inadequate decisions caused by inefficient analyze of thermograms. The lack of correct information about values of impact factors including an emissivity coefficient in industrial conditions becomes a decisive.

Therefore, enhancing the accuracy of temperature/temperature gradient measurements of object surface and developing of temperature measurement methodology in production cycles becomes more and more important.
\end{abstract}

Key words: Radiation thermometer, Emissivity, Background radiation, Infrared radiation, Measurement accuracy.

Анотація. Із метою технічного діагностування об’єктів проаналізовано результати вимірювання температури за інфрачервоним випроміненням та визначено градієнт температури поверхні об’єкта дослідження. Обидва показники інформують про особливості зовнішньої та внутрішньої будови об'єктів, наявні дефекти та їх розташування. Як результат, така інформація $є$ важливою під час планування та проведення профілактичних заходів, виконання ремонту чи організації подальших уточнювальних досліджень.

На світовому ринку багато компаній виробляе радіаційні термометри, тепловізори та інфрачервоні камери. Це зумовлено використанням доступних та високотехнологічних матричних детекторів випромінювання і мікропроцесорів, а також можливістю розроблення інтерактивного та доступного користувачеві програмного забезпечення. Власне тому ці вимірювальні прилади малогабаритні, характеризуються низьким енергоспоживанням із високою продуктивністю і можливістю опрацювання інформації у режимі реального часу. Це сприяє розширенню їх використання у промисловості.

Проте низька точність вимірювання температури за інфрачервоним випроміненням може призвести до хибного трактування термограм, формування помилкових висновків та прийняття неправильних рішень. Це пов'язано 3 відсутністю достовірної інформації про значення факторів впливу в реальних умовах функціонування об'єктів дослідження, а саме коефіцієнта випромінення поверхні досліджуваного об'єкта, пропускання проміжного середовища та фонового випромінення.

Саме тому важливим є підвищення точності вимірювання температури та градієнта температур у промисловості, зокрема, за допомогою розроблення методів вимірювання, які можна використовувати в реальних умовах.

Ключові слова: радіаційний термометр, випромінювальна здатність, фонове випромінювання, інфрачервоне випромінювання, точність вимірювань

\section{Introduction}

In industry, medicine and research, the application of infrared radiation thermometers and infrared cameras for temperature measurement and temperature gradient analysis is expanding. It allows also thermal monitoring, state diagnostics, and detection of defects. The advantages of using the infrared radiation thermometers and infrared cameras [1] are following:

- wide range of measuring temperatures $50 \div 2500{ }^{\circ} \mathrm{C}$;

- short duration of measurements $-\sim 10^{-6} \mathrm{~s}$;
- ability of moving objects measurements including the measurements in aggressive environment and under high electrical potential.

However, the problem of radiation temperature measurement seems to be insufficient accuracy.

\section{Purpose of the article}

The aim of the current work is to improve the accuracy of infrared temperature measuring means while operation by studying their peculiarities. 
3. Radiation temperature measurements. Analysis of accuracy problem

\subsection{Difference of radiation}

temperature measurement process in different measurement conditions

According to the Planck's law the output signal of the radiation thermometer in ideal operating conditions $S_{i d}\left(\lambda, T_{b b}\right)$ is presented by equation [2-5]:

$$
\begin{gathered}
S_{i d}\left(\lambda, T_{b b}\right)=\int_{\lambda_{1}}^{\lambda_{2}}\left(R(\lambda) \cdot C_{1} \lambda^{-5}\left(e^{\frac{C_{2}}{\lambda T_{b b}}}-1\right)^{-1}\right) d \lambda, \quad \text { (1) } \begin{array}{l}
\text { The output signal of the radiation detector in calibra } \\
\text { condition } S_{c}\left(\lambda, T_{b b c}\right) \text { is presented by: }
\end{array} \\
S_{c}\left(\lambda, T_{b b c}\right)=\int_{\lambda_{1}}^{\lambda_{2}} R(\lambda) \cdot \tau\left(\lambda, T_{a m b}\right)\left[\varepsilon\left(\lambda, T_{b b c}\right) \cdot C_{1} \lambda^{-5}\left(e^{\frac{C_{2}}{\lambda T_{b b c}}}-1\right)^{-1}+\left(1-\varepsilon\left(\lambda, T_{b b c}\right) \cdot C_{1} \lambda^{-5}\left(e^{\frac{C_{2}}{\lambda T_{b s}}}-1\right)^{-1}\right] d \lambda \approx\right. \\
\approx \int_{\lambda_{1}}^{\lambda_{2}} R(\lambda) \cdot \tau\left(\lambda, T_{a m b}\right) \varepsilon\left(\lambda, T_{b b c}\right) \cdot C_{1} \lambda^{-5}\left(e^{\frac{C_{2}}{\lambda T_{b b c}}}-1\right)^{-1} d \lambda
\end{gathered}
$$

where $\tau\left(\lambda, T_{a m b}\right)$ is the transmission factor of intermediate environment in real conditions; $\varepsilon\left(\lambda, T_{b b c}\right)$ is the real emissivity factor of the reference black body cavity;

$$
S_{r c}\left(\lambda, T_{o b}\right)=\int_{\lambda_{1}}^{\lambda_{2}} R(\lambda) \cdot \tau\left(\lambda, T_{a m b}\right)\left[\varepsilon\left(\lambda, T_{o b}\right) \cdot C_{1} \lambda^{-5}\left(e^{\frac{C_{2}}{\lambda T_{o b}}}-1\right)^{-1}+\left(1-\varepsilon\left(\lambda, T_{o b}\right) \cdot C_{1} \lambda^{-5}\left(e^{\frac{C_{2}}{\lambda T_{b s}}}-1\right)^{-1}\right] d \lambda,\right.
$$

where $\varepsilon\left(\lambda, T_{o b}\right)$ is the emissivity of the object's surface. Really, the temperature $T_{o b}$, the emissivity factor $\varepsilon\left(\lambda, T_{o b}\right)$ of object's surface and the transmission factor of intermediate environment $\tau\left(\lambda, T_{a m b}\right)$ are unknown. Values of different impact factors of radiation temperature measurements, presented in Tabl. 1, concerned the probable operation conditions.

Values of different influent factors of radiation temperature measurements

\begin{tabular}{|c|c|c|c|}
\hline $\begin{array}{c}\text { Radiation temperature } \\
\text { measurement condition }\end{array}$ & $\begin{array}{c}\text { Object's emissivity } \\
\text { factor }\end{array}$ & $\begin{array}{c}\text { Temperature of } \\
\text { background radiation } \\
T_{b g},{ }^{\circ} \mathrm{C}\end{array}$ & $\begin{array}{c}\text { Transmission coefficient } \\
\text { of intermediate environment } \\
\tau\left(\lambda, T_{a m b}\right)\end{array}$ \\
\hline $\begin{array}{c}\text { Ideal condition of radiation } \\
\text { temperature measurement }\end{array}$ & $\begin{array}{c}\text { Blackbody surface } \\
\varepsilon\left(\lambda, T_{b b}\right)=1.00\end{array}$ & 0 & 1.00 \\
\hline $\begin{array}{c}\text { Condition of radiation } \\
\text { thermometer calibration }\end{array}$ & $\begin{array}{c}\text { Blackbody cavity surface } \\
\varepsilon\left(\lambda, T_{b b c}\right) \\
0.99\end{array}$ & $20 \pm 2{ }^{\circ} \mathrm{C}$ & 1.00 \\
\hline $\begin{array}{c}\text { Real condition of radiation } \\
\text { temperature measurement }\end{array}$ & $\begin{array}{c}\text { Real object's surface } \\
\varepsilon\left(\lambda, T_{o b}\right) \\
0.3<\varepsilon<1\end{array}$ & $0{ }^{\circ} \mathrm{C}<T_{b g}<5000^{\circ} \mathrm{C}$ & $0.8<\tau<1$ \\
\hline
\end{tabular}


Difference between ideal output signals in calibration and real measurement conditions causes the significant errors of measurement results. This fact restricts the widespread use of the radiation thermometers in practical temperature measurements in industry, scientific research and medicine.

\subsection{The simulation results of output} signals depending of values of the influence factors

The simulation results of temperature dependence of output signal (for radiation detector of
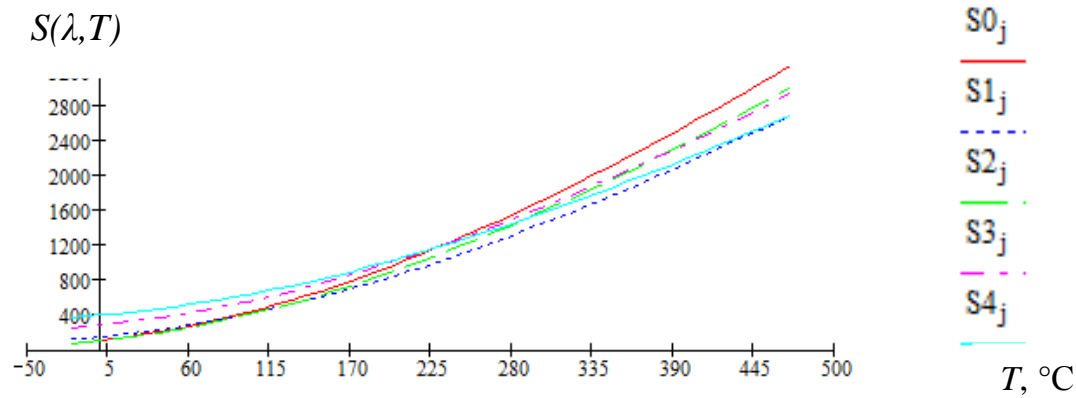

Figure 1. Temperature dependency graphs of the detector's output signal for different conditions:

$$
\begin{gathered}
S O_{j}: \varepsilon=1.00, \tau=1.00, T_{b g}=0{ }^{\circ} \mathrm{C} ; \\
S 1_{j}: \varepsilon=0.85, \tau=0.95, T_{b g}=100{ }^{\circ} \mathrm{C} ; \\
S 2_{j}: \varepsilon=0.95, \tau=0.97, T_{b g}=0{ }^{\circ} \mathrm{C} ; \\
S 3_{j}: \varepsilon=0.85, \tau=0.99, T_{b g}=250{ }^{\circ} \mathrm{C} \text {; } \\
S 4_{\mathrm{j}}: \varepsilon=0.75, \tau=0.97, \mathrm{~T}_{\mathrm{bg}}=250^{\circ} \mathrm{C} .
\end{gathered}
$$

\subsection{The uncertainty component of type $B$} of radiation temperature measurement method

The influence of uncertainty parameters of type B of radiation thermometry is examined in [7-9]: the instrument uncertainty components (the noise of detector; the spectral sensitivity changes in optical receiving system and non-linearity of conversion; the influence of external temperature; changes in spatial and temperature sensitivity) and the uncertainty components of measurement method.

The main uncertainty components of type B, caused by the peculiarities of the infrared radiation measurement method, are described by the equation [7], [10]:

$$
u_{B(\text { method })}(S(\lambda, T))=\sqrt{C_{\varepsilon}^{2} u^{2}\left(\varepsilon\left(\lambda, T_{o b}\right)\right)+C_{\tau}^{2} u^{2}\left(\tau\left(\lambda, T_{a m b}\right)\right)+C_{T_{b g}}^{2} u^{2}\left(\lambda, T_{b g}\right)},
$$

where $C_{\varepsilon}$ is the sensitivity coefficient of the influence of the object's surface emissivity; $C_{\tau}$ is the sensitivity coefficient of the influence of the intermediate environment transmission; $C_{T_{b g}}$ is the sensitivity coefficient of the influence of the background radiation; $u\left(\varepsilon\left(\lambda, T_{o b}\right)\right)$ is the uncertainty component of infrared radiation temperature measurement of the influence of the emissivity; $u\left(\tau\left(\lambda, T_{a m b}\right)\right)$ is the uncertainty component of infrared radiation temperature measurement of the influence of intermediate environment; $u\left(\lambda, T_{b g}\right)$ is the uncertainty component of radiation temperature measurement of the influence of background radiation.

We have investigated the uncertainty of the infrared radiation temperature measurements in operating conditions. The modelling of uncertainty of non-contact temperature measurement method demonstrates that in the range $50-500{ }^{\circ} \mathrm{C}$ the uncertainty can reach tens and hundreds of degrees. Fig. 2 presents separate results of the simulation of radiation measurement uncertainty. It makes possible to give the quantitative assessment of the accuracy, to compare the results and to evaluate the influence of various factors on the obtained results.

The multiband measurement methods [11-15] and testing methods [16] enable to process the spectral information on the influential factors and to determine 
them. The application of multiband measurement methods allows the increasing the accuracy of infrared radiation temperature measurement. Unfortunately, these methods make it possible to determine only the value of

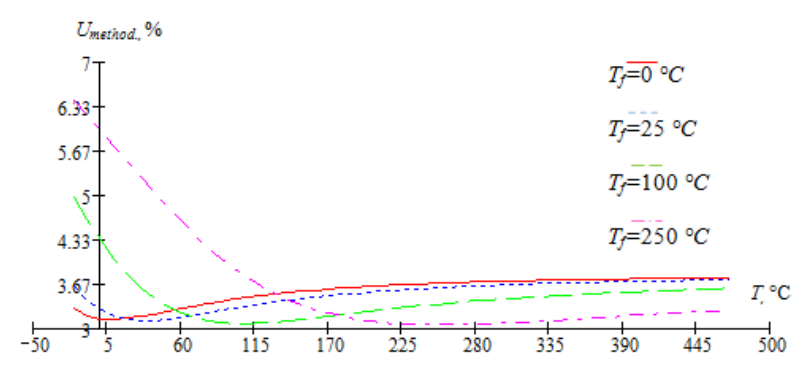

Figure 2a. Graph of relative uncertainty dependence on the influence of background radiation at $\varepsilon=0.75$ and $\tau=0.95$

Thus, for increasing the accuracy of radiation temperature measurements explorer has to know full information about impact factors. emissivity, but ignore the information about the influence of background radiation and the intermediate environment on the temperature measurement results [17], [18].

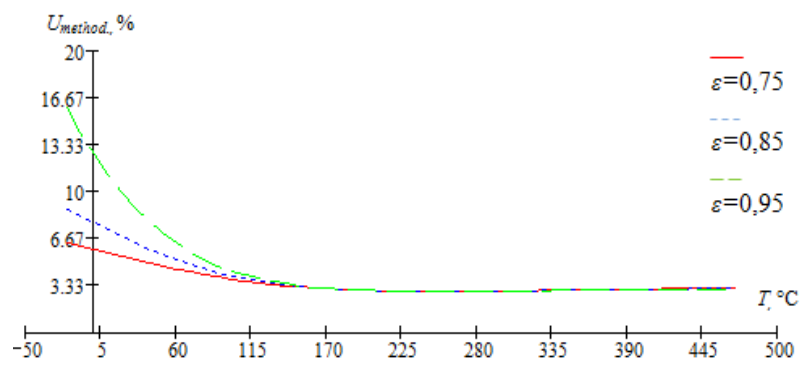

Figure $2 b$. Graph of relative uncertainty dependence on the influence of the radiation coefficient at $T_{b g}=250^{\circ} \mathrm{C}$ and $\tau=0.99$

While operating the values of these factors are unknown. As a result, a new approach is needed.
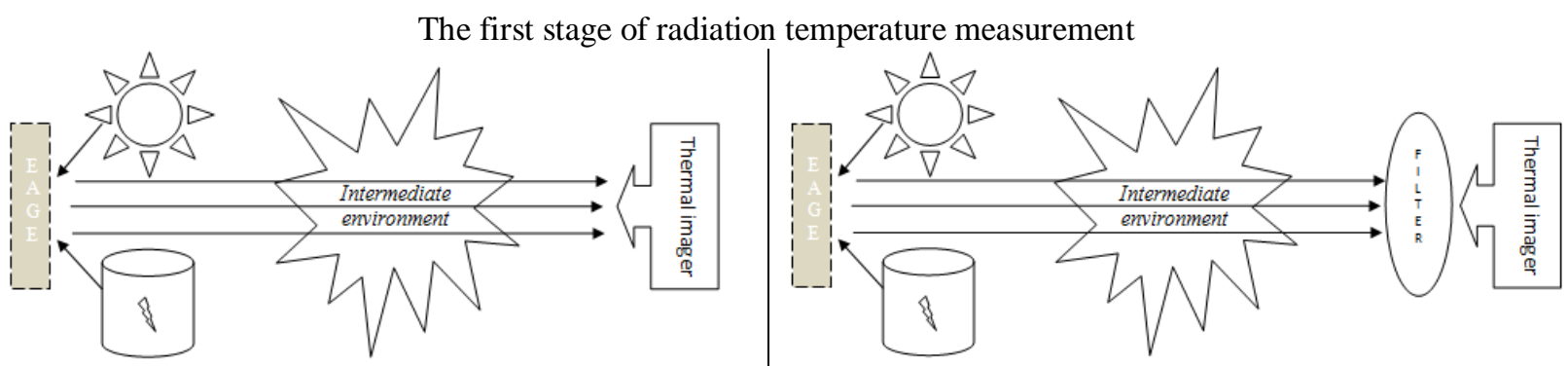

The second stage of radiation temperature measurement
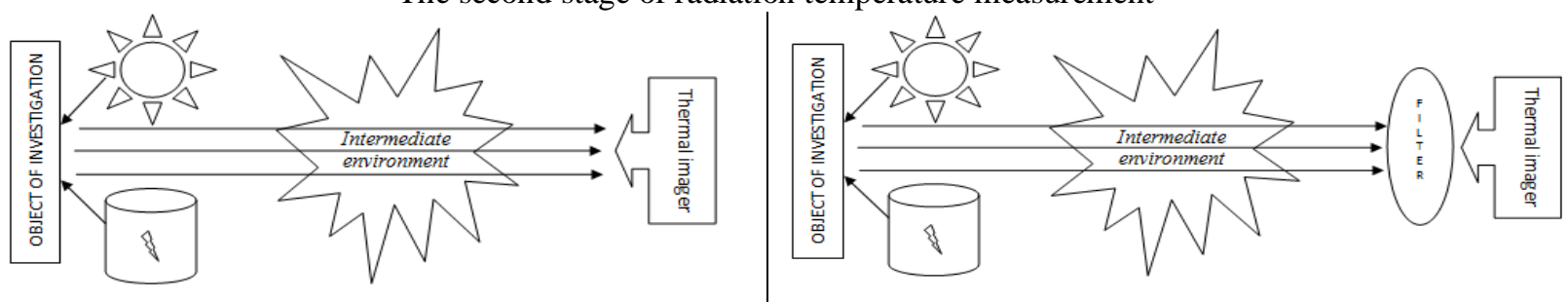

Figure 3. Scheme for implementing the method of increasing the infrared radiation temperature measurement accuracy

\section{Method of increasing}

of IR temperature measurement accuracy in operating conditions

We propose the method of temperature measurement in two spectral bands. It is implemented with using the temperature information-measuring system, which consists of radiation thermometers, a system of external filters, a computer and a reference grey body.

(Fig. 3)

\subsection{Scheme for implementing the method}


bands. The system of output signals equations in both spectral bands $S_{p, q}^{11}(\lambda)$ and $S_{p, q}^{21}(\lambda)$ looks like (5). When the system of equations is solved, we obtain the values of the influential factors that characterize the research conditions. Then, we carry out the calculation and enter into the radiation thermometer the data on transmission coefficients and temperature of background.

$$
\left\{\begin{array}{l}
S_{p, q}^{11}(\lambda)=\tau\left(\varepsilon_{r g b} \int_{\lambda_{11}}^{\lambda_{21}} C_{1} \lambda^{-5}\left(e^{\frac{C_{2}}{\lambda T_{r g b}}}-1\right)^{-1} d \lambda+\left(1-\varepsilon_{r g b}\right) \int_{\lambda_{11}}^{\lambda_{21}} C_{1} \lambda^{-5}\left(e^{\frac{C_{2}}{\lambda T_{d g}}}-1\right)^{-1} d \lambda\right) \\
S_{p, q}^{21}(\lambda)=\tau\left(\varepsilon_{r g b} \int_{\lambda_{12}}^{\lambda_{22}} C_{1} \lambda^{-5}\left(e^{\frac{C_{2}}{\lambda T_{r g b}}}-1\right)^{-1} d \lambda+\left(1-\varepsilon_{r g b}\right) \int_{\lambda_{12}}^{\lambda_{22}} C_{1} \lambda^{-5}\left(e^{\frac{C_{2}}{\lambda T_{b g}}}-1\right)^{-1} d \lambda\right)
\end{array} .\right.
$$

Implementation of the first stage of the method involves the following actions:

- formation of a measuring system: a reference grey body, a filter installation with two spectral bands $\lambda_{11} \div \lambda_{21}$ and $\lambda_{12} \div \lambda_{22}$; a radiation thermometer or infrared camera, a computer;

- heating the reference grey body to a temperature $T_{r g b}$;

- process of measuring the surface temperature of the reference grey body in two spectral bands $\lambda_{11} \div \lambda_{21}$ and $\lambda_{12} \div \lambda_{22}$;

- registration of output signals of the radiation thermometer in two spectral bands $S_{p, q}^{11}(\lambda)$ and $S_{p, q}^{21}(\lambda)$
- formation of equations (5);

- solving the equations (5) and determining the transmission coefficient of intermediate environment $\tau$ and the temperature $T_{r g b}$. of background radiation while measuring.

2. Second, we determine the values of the emissivity coefficient $\varepsilon_{o b}$ and the object's surface temperature $T_{o b}$ for two color radiation thermometer that measures the surface temperature of the object. The values of the emissivity coefficient and surface temperature are calculated by the output signals of the radiation detector in two spectral bands. As a result, we obtain the system of two equations of output signals for both spectral bands $S_{p, q}^{12}(\lambda)$ and $S_{p, q}^{22}(\lambda)$ :

$$
\left\{\begin{array}{l}
S_{p, q}^{12}(\lambda)=\tau \quad\left(\varepsilon_{p, q} \int_{\lambda_{11}}^{\lambda_{21}} C_{1} \lambda^{-5}\left(e^{\frac{C_{2}}{\lambda T_{p, q}}}-1\right)^{-1} d \lambda+\left(1-\varepsilon_{p, q}\right) \int_{\lambda_{11}}^{\lambda_{21}} C_{1} \lambda^{-5}\left(e^{\frac{C_{2}}{\lambda T_{f}}}-1\right)^{-1} d \lambda\right) \\
S_{p, q}^{22}(\lambda)=\tau\left(\varepsilon_{p, q} \int_{\lambda_{12}}^{\lambda_{22}} C_{1} \lambda^{-5}\left(e^{\frac{C_{2}}{\lambda T_{p, q}}}-1\right)^{-1} d \lambda+\left(1-\varepsilon_{p, q}\right) \int_{\lambda_{12}}^{\lambda_{22}} C_{1} \lambda^{-5}\left(e^{\frac{C_{2}}{\lambda T_{f}}}-1\right)^{-1} d \lambda\right)
\end{array} .\right.
$$

Implementation of the second stage involves the following actions:

- $\quad$ process of measuring the surface temperature of the object in two spectral bands $\lambda_{11} \div \lambda_{21}$ and $\lambda_{12} \div \lambda_{22}$;

- registration of output signals of the radiation thermometer in two spectral bands $S_{p, q}^{12}(\lambda)$ and $S_{p, q}^{22}(\lambda)$;

- formation of a system (6);

- solving this system (6) and determining the values of the emissivity coefficient $\varepsilon_{o b}$ and of object's surface temperature $T_{o b}$.

While solving the appropriate system (6), we obtain the value of the emissivity $\varepsilon_{o b}$ and temperature $T_{o b}$ in operating conditions. The solution of these equations systems is carried out by a microprocessor, which controls the operation of the measuring system.
To determine the true temperature value $T_{o b}$, the microprocessor automatically enters the values of the influential factors $\tau, T_{b g}, \varepsilon_{o b}$. Herewith, it is important to use a linear or linearized calibration function IR detector of radiation thermometer [18].

When this method is applied to IR camera, the true values of the object's surface point temperatures can be calculated. As a result, it provides the possibility to receive a thermogram with the temperatures distribution of the object's surface temperature field. It enables not only to carry out a qualitative analysis of thermo grams, and also a quantitative analysis of the object's surface thermal field.

The results of simulation confirming the possibility of the studied method are presented below (Table 2). We can see that the algorithm of the proposed method gives the possibility of obtaining values that are in line with the actual values of the temperature. 
Results of simulation of the method of increasing accuracy of IR temperature measurement

Table 2

\begin{tabular}{|c|c|c|c|c|c|c|}
\hline \multirow{2}{*}{$\begin{array}{l}\text { Temperature } \\
\text { values, }{ }^{\circ} \mathrm{C}\end{array}$} & \multicolumn{3}{|c|}{$\begin{array}{l}\text { Values of influencing } \\
\text { factors }\end{array}$} & \multirow{2}{*}{$\begin{array}{c}\text { Calculated } \\
\text { temperature } \\
\text { values, } \\
{ }^{\circ} \mathrm{C} \\
\end{array}$} & \multirow[t]{2}{*}{ Absolute deviation, ${ }^{\circ} \mathrm{C}$} & \multirow{2}{*}{$\begin{array}{l}\text { Relative deviation } \\
\text { (for K) }\end{array}$} \\
\hline & $\varepsilon$ & $\tau$ & $T_{b g},{ }^{\circ} \mathrm{C}$ & & & \\
\hline-20 & 0.80 & 0.90 & 21 & -15.3999 & 4.6001 & 1.8171 \\
\hline 10 & 0.95 & 0.93 & 250 & 28.8647 & 18.8647 & 6.6625 \\
\hline 30 & 0.99 & 0.95 & -10 & 26.2828 & -3.7172 & -1.2262 \\
\hline 100 & 0.75 & 0.97 & 0 & 78.1421 & -21.8579 & -5.8577 \\
\hline 250 & 0.90 & 0.99 & 100 & 235.9553 & -14.0447 & -2.6846 \\
\hline 470 & 0.85 & 1.00 & 50 & 423.5431 & -46.4569 & -6.2514 \\
\hline-20 & 0.75 & 0.90 & 250 & 80.5711 & 100.5711 & 39.7279 \\
\hline
\end{tabular}

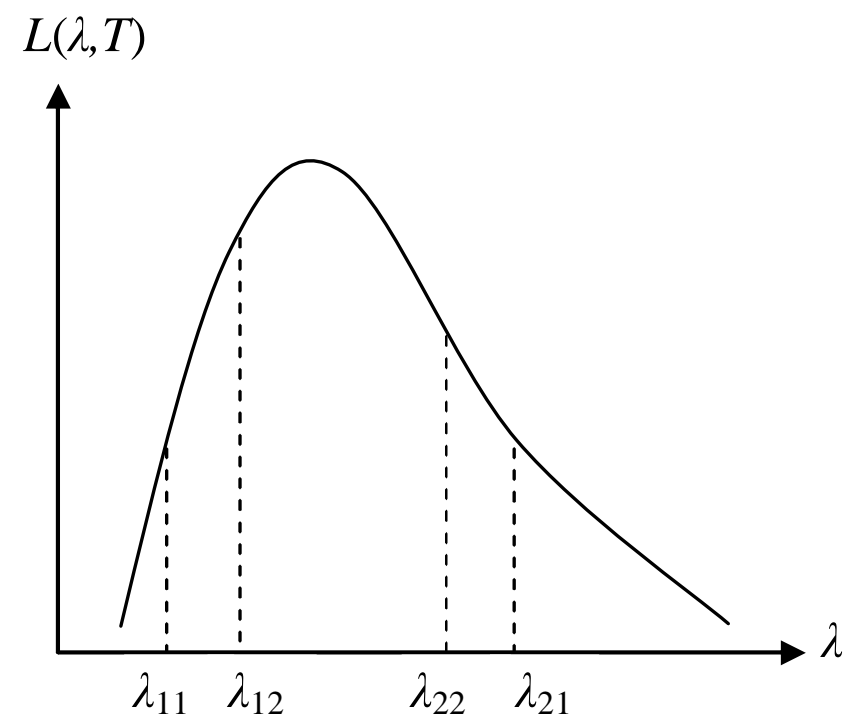

Figure 4. Working spectral bands based on the "band in band" principle on the example of the radiation intensity according to Planck's law

The studied method of can increase the accuracy of contactless temperature measurements by one order in comparison to the existing measurement methods indicated by the manufacturers.

\subsection{Spectral channels formation principles}

To implement the measurements in two spectral bands, it is necessary to select them. We propose to choose these bands basing on the "band in band" principle. The meaning of this approach is graphically depicted in Fig. 4.

It can be achieved in the following ways by using:

- the thermal imagers operating in several spectral bands or by conducting the measurements using two thermal imagers (for example, IRE Cooled IR
Cameras - IRE-320M and IRE-640M / BB) that operate in different spectral bands;

- $\quad$ an additional bandpass filter to reduce the width of the working spectral band of the thermal imager optical system (for example, if the spectral band of the radiation thermometer is $8 \div 14 \mu \mathrm{m}$, the bandpass filter can be used to narrow it to $8 \div 10 \mu \mathrm{m}$ ).

During the calculation of the output signals of the radiation receivers in the range of $8 \div 14 \mu \mathrm{m}$ and $8 \div 10$ $\mu \mathrm{m}$, the difference between the values of the signals is sufficient and increasing with the temperature of investigated object's surface (for the ideal value of the output signal of the thermal imager according to Planck's law). The results of calculations are presented in Fig. 5. 


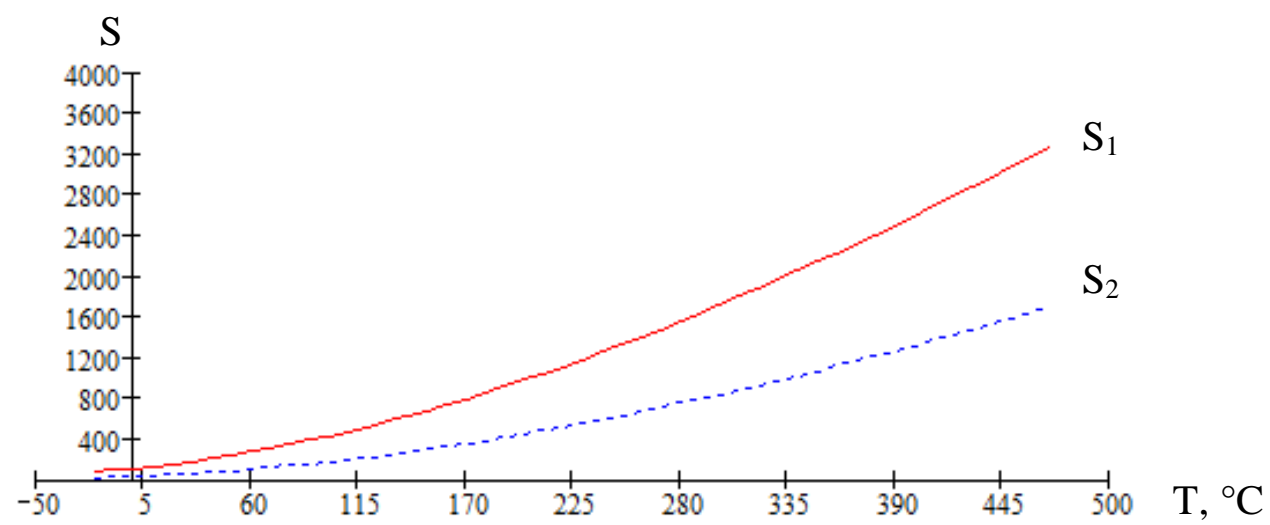

Figure 5. Graphs of the output signal values $S_{1}$ and $S_{2}$ of the thermal imager radiation receiver according to Planck's formula for spectral bands $8 \div 14 \mu \mathrm{m}$ and $8 \div 10 \mu \mathrm{m}$

So, performing of measurements based on the "band in band" principle that means simultaneous observation of the object in different spectral bands, gives more information about object.

\subsection{Reference grey body}

For the realization of this method, we developed the design of reference grey emitter [19]. It has the following characteristics: plane design; the properties of surface emissivity $\varepsilon(\Delta \lambda, \Delta T)<1, \quad \varepsilon(\Delta \lambda, \Delta T)=$ const, $\varepsilon(t)=$ const; and homogeneity of surface temperature. It is possible to correct the surface emissivity of the extended area grey emitter by the following methods: oxidation of the metal surface or deposition of coatings with different emissivity, mechanical surface treatment, and selection of geometry of the surface. For example, the formation of a surface can be implemented by creating the coneshaped cavities on the plane of the extended area grey emitter or by 3D printing of such surface (Fig. 6).

Achieving a stable surface structure provides the minimum drift of emissivity values at a wide its range.

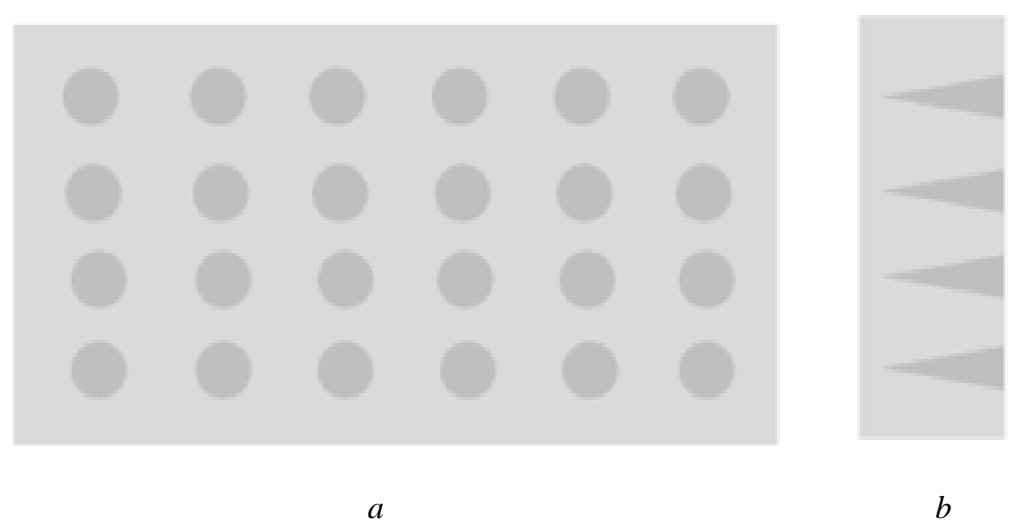

Figure 6. The surface of an extended area grey emitter with drilled cones: $a$ - the top view; $b$ - the side view

The expediency of using such shape is due to the cone property to provide multiple reflections of radiation that enters in its cavity. It helps to sustain the high emissivity coefficient by reducing the reflection coefficient of the area of grey emitter surface.

The considered emissivity coefficients of the grey emitter surface with cones can be altered due to the choice of different materials for this surface, changes in the number of drilled conical cavities, in the radius and depth of cones.

\section{Conclusions}

The considered method can be used for IR temperature measurement under the operating conditions. It provides the correction of the emissivity and the transmission coefficient as well as the background radiation temperature can be inputted into the output signal of radiation receiver. The application of this method for infrared cameras provides the possibility to obtain a thermogram with the real temperature distribution of the thermal field of investigated object's surface and to conduct a quantitative analysis of the 
results of thermal imaging research at increasing the accuracy of IR temperature measurements. The formation of spectral bands based on the principle of "band in band" allows using only one additional filter for the implementation of two-band filtration in this method. The development of method in thermal imagers and IR cameras supplemented by output signals of the object and reference grey body in two spectral bands processing gives the possibility to introduce the temperature corrections to each point of the temperature field, obtaining the real values of the temperatures. This achieves the transition from qualitative to quantitative measurements with definite accuracy.

\section{Acknowledgments}

The authors express their deep gratitude to the staff and the Head of Department of Measuring Information Technologies of Lviv Polytechnic National University for the support and assistance in the scientific research.

\section{Conflict of interest}

The conflict of interest during the writing, preparation and publication of the article is absent, as well as the mutual claims of co-authors.

\section{References}

[1] B. Wiecek, Termowizija $w$ podczerwieni podstawy $i$ zastosowania, Warshawa, Poland: Wydawnictwo PAK, 2011.

[2] G. Ribaud, Traité de pyrométrie optique, Paris, France: Revue d'Optique, 1931.

[3] T. G. Harrison, Radiation pyrometry, Moscow, USSR: Mir, 1964.

[4] M. A. Bramson, Infrared radiation of heated bodies, Moscow, USSR: Science, 1964.

[5] A. N. Gordov, Fundamentals of pyrometry, Moscow, USSR: Metallurgy, 1971.

[6] G. Gossorg, Infrared Thermography. Principles, Techniques, Application, Moscow, USSR, 1988.
[7] N. Hots, "Investigation of temperature measurement uncertainty components for infrared radiation thermometry", Adv. in Intel. Systems and Comp., no. 543, pp. 556-566, 2017.

[8] W. Minkina, and S. Dudzik, Infrared thermography: errors and uncertainties. Chichester, United Kingdom: John Wiley \& Sons Ltd, 2009.

[9] N. Hots, and T. Piątkowski, "Analiza czynników składowych błędów pirometrii radiacyjnej”, Pomiary. Automatyka. Kontrola, no. 11, pp. 874-877, 2009.

[10] JCGM 100:2008 Evaluation of measurement data - Guide to the expression of uncertainty in measurement. International Organization for Standardization-International Electrotechnical Commission-International Organization of Legal Metrology-International Bureau of Weights and Measures, September 2008. [Online]. Available: https://www.bipm.org/utils/common/ documents/jcgm/JCGM_100_2008_E.pdf.

[11] D. Y. Svet, Optical measuring methods of true temperature, Moscow, USSR: Science, 1982.

[12] V. N. Snopko, Spectral methods of optical pyrometry of heated surface, Minsk, Belarus: Science and technology, 1988.

[13] V. N. Snopko, Wide-spectral optical pyrometer: Part 1, Minsk, Belarus, Preprint / Institute of Physics Academy of Sciences of Belarus, 1993.

[14] V. N. Snopko, "Methods of optimal polychromatic pyrometry", Thermophysics of High Temperature, vol. 25, no. 5, pp. 980-986, 1987.

[15] D. Y. Svet, Objective methods of high-temperature pyrometry under a continuous spectrum of radiation, Moscow, USSR: Science, 1968.

[16] E. Bromberg, and K. Kulikovskiy, Testing methods of improving of measurement accuracy, Moscow, USSR: Energy, 1978.

[17] N. Hots, "Comparative characteristics of pyrometry methods", Devices + Automation, no. 7 (85), pp. 35-50, 2007.

[18] N. Hots, "Method of control and linearization of calibration function for reference infrared radiation thermometer", in 13th International Conference on Modern Problems of Radio Eng., Telecom. and Comp. Sc. (TCSET), Lviv, Ukraine, pp. 308-311, 2016.

[19] N. Hots, and Yu. Dzikovska, "Development of Extended Area Grey Emitter for Usage in the Temperature Measurements by Infrared Radiation", Metrology and Devices, no. 2 (64), pp. 23-29, 2017. 